\title{
Erratum to: The Ideology and Practice of Pacific Herring Cultivation among the Tlingit and Haida
}

\author{
Thomas F. Thornton ${ }^{1}$
}

Published online: 2 July 2015

(C) Springer Science+Business Media New York 2015

Erratum to: Hum Ecol (2015) 43:213-223

DOI 10.1007/s10745-015-9736-2

The author would like to point out that the correct transcription for the Tlingit phrase for sustainability (right hand column on p. 4 para 2, lines 3-4 in the original version) should be "woosh eetíx" not "wooch.ee tíx". The correct sentence should read: Going "with nature" on the other hand meant enhancing the integrity and productivity of life through cultivation techniques that sustained life, "keeping it living," or in Tlingit, woosh eetix' [?] ("[keeping them] growing behind each other [i.e.,replacing each other]," according to elder Clarence Jackson, pers. comm.).

The online version of the original article can be found at http://dx.doi.org/ 10.1007/s10745-015-9736-2.

Thomas F. Thornton

thomas.thornton@ouce.ox.ac.uk

1 University of Oxford, Oxford, UK 